\title{
Synthesis, Characterization, 3D Modeling, Biological Activities of Some Metal Complexes of Novel Sulpha DrugSchiff Base Ligand and Its Nano Cu Complex
}

\author{
Tarek M. Ismail ${ }^{*}$, Mosad A. EL Ghamry, Samy M. Abu-El-Wafa, Doaa F. Sallam \\ Department of Chemistry, Faculty of Education, Ain Shams University, Roxy, Cairo, Egypt
}

Email address:

tarek.ismail70@yahoo.com (T. M. Ismail)

To cite this article:

Tarek M. Ismail, Mosad A. EL Ghamry, Samy M. Abu-El-Wafa, Doaa F. Sallam. Synthesis, Characterization, 3D Modeling, Biological Activities of Some Metal Complexes of Novel Sulpha Drug Schiff Base Ligand and Its Nano Cu Complex. Modern Chemistry.

Vol. 3, No. 2, 2015, pp. 18-30. doi: 10.11648/j.mc.20150302.12

\begin{abstract}
Novel solid $\mathrm{Co}(\mathrm{II}), \mathrm{Ni}(\mathrm{II}), \mathrm{Cu}(\mathrm{II})$ and $\mathrm{Zn}$ (II) complexes of sulpha drug Schiff base ligand (HL) derived from condensation of sulphaquinoxaline and naphthaldehyde namely, 2-\{4-[(2-hydroxynaphthalen-1-yl) methyleneamino] benzenesulfonamido quinoxalin (HNMABSQ), in addition new mixed ligand complexes with 8-hydroxyquinoline (8-HQ) or 1,10 Phenanthroline (1,10 Phen) with HL and these metal (II) ions were synthesized. The structure of complexes were proposed in light of analytical, IR, ${ }^{1} \mathrm{H}-\mathrm{NMR}$, Mass, UV-Vis, ESR spectral data, magnetic and thermal studies. The molar conductance data reveal that all the metal chelates were non-electrolytes. The kinetic and thermodynamic parameters for decomposition steps in $\mathrm{Co}(\mathrm{II}), \mathrm{Ni}(\mathrm{II})$ and $\mathrm{Cu}(\mathrm{II})$ complexes thermo grams were calculated. On the basis of these studies, most complexes have octahedral geometry but few can attain the square planar arrangement. 3D modeling of the ligand and its metal complexes were studied by PM3 method, also the heat of formations, HOMO, LUMO and dipole moments were calculated to confirm the geometry of the ligand and its complexes. Schiff base ligand and its metal complexes were tested for antimicrobial activities. Nano-Cu- Schiff base complex was synthesized and characterized by scanning electron microscopy (SEM) and its biological activities were studied. The $\mathrm{Cu}$ nano complex had higher antibacterial and antifungal activity than the ligand and its metal complexes. Also, all tested compounds inhibited the growth of the liver cancer cell.
\end{abstract}

Keywords: Sulphaquinoxaline, Schiff Base, Metal Complexes, Spectral Studies, Antimicrobial, Anticancer Activity, Nano Complexes

\section{Introduction}

Extensive research of Schiff bases have been carried out due to their interesting and important properties, such as their ability to form complexes with most transition metal ions and for their biological activity such as antibacterial, antifungal and antitumor activities [1-4]. Metal complexes of Schiff bases have been investigated because they play an important role not only in the development in coordination chemistry, but also in catalysis, enzymatic reaction, magnetism, molecular architectures [5-7] and exhibit biological applications and pharmaceutical activities [8-10].

Sulphaquinoxaline compounds are largely used as antibacterial [8] antifungal [9] and antitumor [10, 11]. The metal complexes of Schiff base derived from sulfa drugs have gained considerable importance due to their having good complexion ability [12-15]. They exhibit also a range of bioactivities, including antitumor, anti-inflammatory, antitubercular, anti-glaucoma, anti-microbial and anti malarial agent [16-22].

Recently, nano materials have been receiving increased attention due to their tremendous applications in the field of catalysis, sensor technology and fabrication of ultramodern electronic devices [23, 24]. Preparing pure transition-metal nano materials is an important topic [25, 26].Schiff base ligand and nano Schiff-base-Cu complexes inhibited the growth of the liver cancer cell [27, 28]

So, the present work aimed to synthesize and characterize $\mathrm{Co}$ (II), Ni (II), $\mathrm{Cu}$ (II) and $\mathrm{Zn}$ (II) metal complexes with newly synthesized sulpha drug Schiff base ligand derived from sulphaquinoxaline and naphthaldehyde. The Schiff base ligand, its metal complexes and its $\mathrm{Cu}$-nano complex were tested for antibacterial and antifungal activities. The $\mathrm{Cu}$ nano Schiff base complex had higher antimicrobial activity than 
the ligand and its metal complexes. Also, all tested compounds inhibited the growth of the liver cancer cell.

\section{Experimental}

\subsection{Materials}

The chemicals used were obtained from Aldrich, BDH or Merck products. The solvents used were ethanol, isopropanol, DMF and diethylether. These solvents were either spectroscopically pure or purified by the recommended methods [29] and were tested for their spectral purity.

\subsection{The Apparatus and Physical Measurement}

Melting points were determined on a digital Stuart $\mathrm{SMP}^{-3}$ apparatus. Elemental microanalyses were performed at Microanalysis Center in National Research Center, Giza, Egypt. The electronic absorption spectra of the ligand and their complexes in DMF were recorded at room temperature within the wavelength range $200-800 \mathrm{~nm}$ by the aid of UVVis spectrophotometer (Shimadzu UV-1601PC). The FT-IR spectra (4000-400 $\left.\mathrm{cm}^{-1}\right)$ of the compounds were recorded as $\mathrm{KBr}$ discs using FT-IR (Nicolet is 10) spectrophotometer. ${ }^{1} \mathrm{H}-$ NMR spectra were recorded using a Varian spectrometer, FT290, $90 \mathrm{MHz}$ at Microanalytical Center, Cairo University, Giza, Egypt. Deuterated DMSO-d6 was used as a solvent and tetramethylsilane (TMS) as an internal reference. Mass spectra of the compounds were recorded on a Shimadzu QP2010 plus spectrometer at Microanalytical Center, Cairo University, Giza, Egypt. Samples fragmentations were carried out at $300{ }^{\circ} \mathrm{C}$ and $70 \mathrm{eV}$. Molar conductance values of complexes in DMF solution $\left(10^{-3} \mathrm{M}\right)$ were measured using WTWD-812 Weilheium-conductivity meter model LBR, fitted with a cell model LTA100 at Faculty of Education, Ain Shams University, Cairo, Egypt. Thermal gravimetric analysis (TGA) data were obtained using a Shimadzu TGA$50 \mathrm{H}$ instrument in Faculty of Education, Ain Shams University, Cairo, Egypt. The data measured from the room temperature up to $800{ }^{\circ} \mathrm{C}$ at a heating rate of $10{ }^{\circ} \mathrm{C} / \mathrm{min}$. using nitrogen atmosphere. Magnetic susceptibilities of the complexes were measured by the Gouy's method at room temperature using a Magnetic Susceptibility Balance (Johnson Matthey), Alfa product, Model No. (MKI).Effective magnetic moments were calculated from the expression $\mu_{\text {eff }}=$ $2.828\left(\mathrm{X}_{\mathrm{M}} \mathrm{T}\right)^{1 / 2}$ B. M., where $\mathrm{X}_{\mathrm{M}}$ is the molar susceptibility corrected using Pascal's constants for the diamagnetism of all atoms in the compounds .ESR spectral data were recorded on a Bruker, E500, X-band spectrometer at Radiation Technology Center, Cairo, Egypt. Scanning electron microscope images (SEM) were recorded usingJSM-6360 model at City of science researches and technological application, New Borg El-Arab City, Alexandria, Egypt. 3Dmodeling of the compounds were studied using the molecular modeling program Hyper Chem. The biological activities of the synthesized compounds were studied for antimicrobial activity using disc-agar diffusion method (Bauer - Kirby 1966 \& CLSI 2006). Anti- cancer studies were recorded using Eliza Techn Sunrise $570 \mathrm{~nm}$ filters at Pharmaceutical research center, Cairo, Egypt.

\subsection{Synthesis of Schiff Base Ligand (HL)}

Ethanolic solutions of sulphaquinoxaline (2.5 gm, 0.008 mol) and naphthaldehyde (1.4 gm, $0.008 \mathrm{~mol})$ in 1:1 molar ratio were mixed and refluxed for 8 hours. The orange precipitate was formed, filtered off, recrystallized from ethanol then dried under vacuum to give orange crystal, yield $90 \%$, m.p. $280{ }^{\circ} \mathrm{C}$.

The purity of the prepared Schiff base ligand was examined by elemental analysis, IR, ${ }^{1} \mathrm{H}$ NMR, UV-Vis and mass spectra as the following:

-Anal; Calcd: C, 70.59; H, 7.35; N, 10.29 ,Found: C, 70.19; H, 7.13; N, 9.92

-IR $\quad\left(\mathrm{cm}^{-1}\right) ; \quad$ vOHphenolic $\quad 3355, v \mathrm{C}=\mathrm{N} \quad 1624, \mathrm{NH}$ 3066, $\mathrm{SO}_{2}$ ass 1135 and $\mathrm{SO}_{2}$ sym 1089 .

${ }_{-}^{1} \mathrm{HNMR} ; \delta(\mathrm{ppm}) 3.33$ (s, H, $\left.\mathrm{CH}_{\text {aliphatic }}\right), 6.97-8.28$ (m, $\left.15 \mathrm{H}, \mathrm{CH}_{\text {aromatic }}\right)$ and $6.95-8.19\left(\mathrm{~m}, 13 \mathrm{H}, \mathrm{CH}_{\text {aromatic }}\right)$, respectively, $\delta(8.41)(\mathrm{s}, 1 \mathrm{H})$ was assigned to the azomethine proton $(-\mathrm{N}=\mathrm{CH}-)$ of the Schiff base (HL). Signals at 8.94$9.64(\mathrm{~s}, \mathrm{H}, \mathrm{NH})$ and 12.11-12.47 (s, H, $\left.\mathrm{OH}_{\text {phenolic }}\right)$. The ${ }^{1}$ HNMR spectrum of the ligand HLshowed signal at 15.32 which may be due to $\mathrm{H}$ - bond formation between the phenolic $\mathrm{OH}$ and azomethinegroup. The signals due to the protons of the phenolic $\mathrm{OH}$ groups and $\mathrm{H}$ - bond completely disappeared on adding $\mathrm{D}_{2} \mathrm{O}$ while the other signals still persist at the same positions.

-UV-Vis spectra; $\lambda \max (\mathrm{nm})$, the band located at (282) is due to the low energy $\pi-\pi^{*}$ transition of the aromatic system, the band within the (331) can be assigned to $\pi-\pi^{*}$ transition within the $\mathrm{C}=\mathrm{N}$ groups and the band located at (469) is due to an intermolecular charge transfer within the whole molecule (CT).

-Mass fragmentation spectrum of Schiff base ligand under investigation is shown in Fig. 1. Schiff base ligand fragmentation exhibits the molecular ion peak $(\mathrm{m} / \mathrm{e})=454$, which is the same as that of the molecular weight of the ligand. Generally, the fragmentation of mass spectra of the ligand showed three main pathways, Scheme 1. 

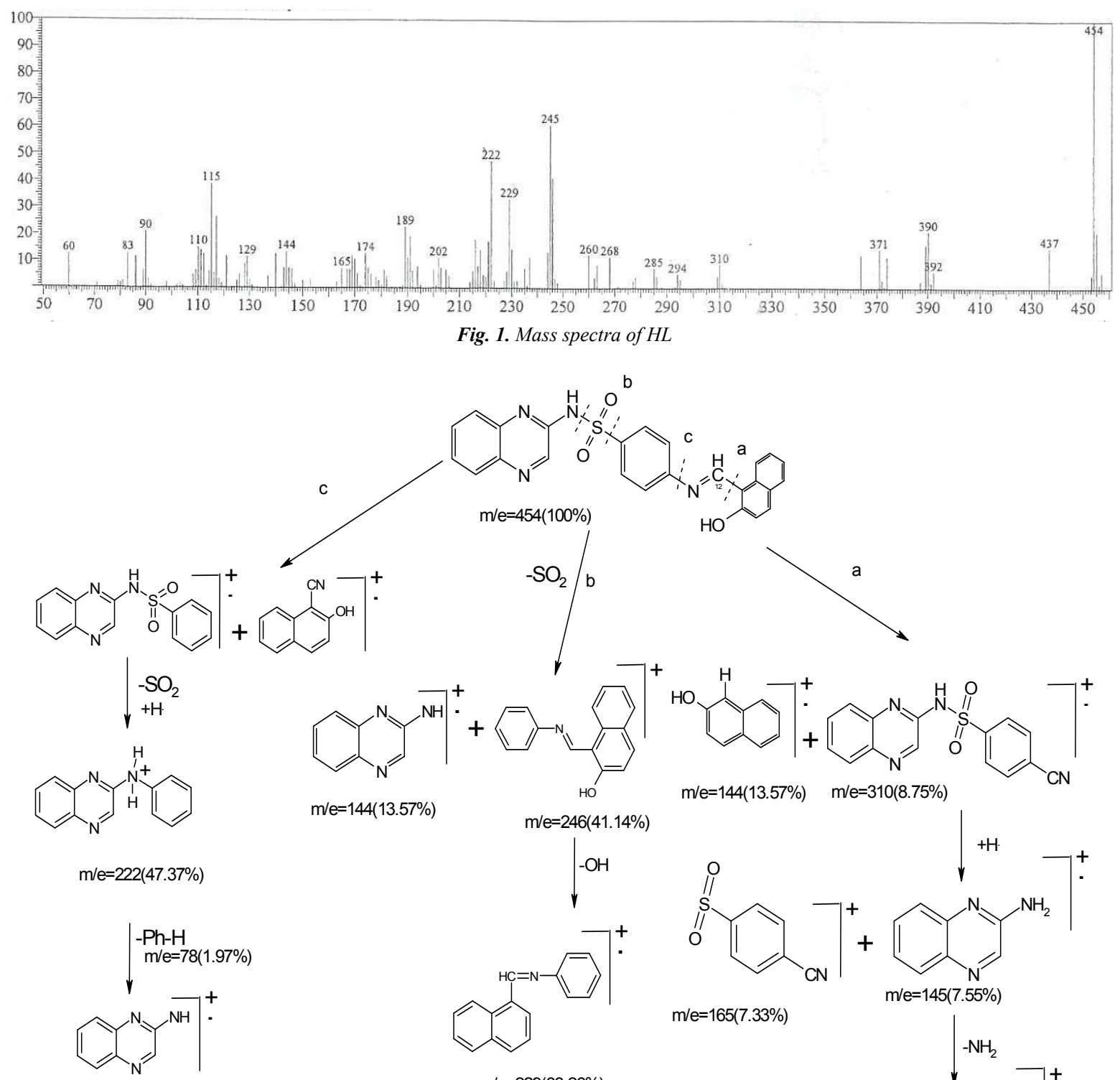

$\mathrm{m} / \mathrm{e}=144(13.57 \%)$

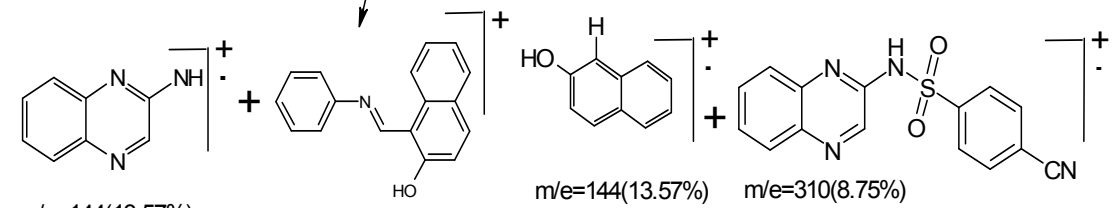

$\mathrm{m} / \mathrm{e}=144(13.57 \%)$
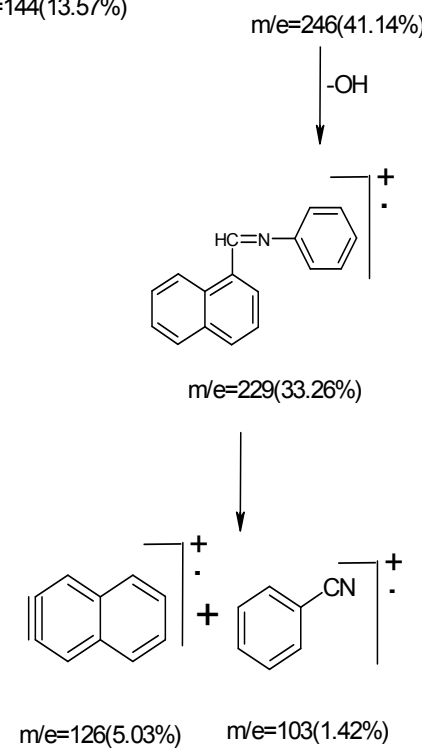

$\mathrm{m} / \mathrm{e}=229(33.26 \%)$

cheme 1. The fragmentation of mass spectra of the ligand

The proposed structure of Schiff base ligand under investigation has the following structural formulae:

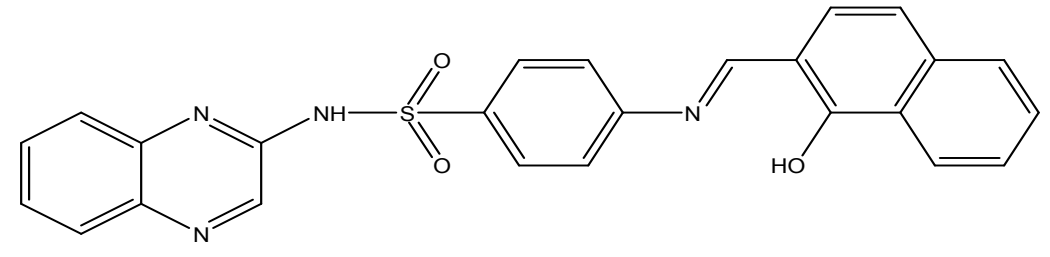

Schiff base ligand (HL)

2-\{4-[(2-hydroxynaphthalen-1-yl) methyleneamino] benzenesulfonamido\}quinoxaline, (HNMABSQ) 


\subsection{Preparation of the Solid Complexes}

Ethanolic solutions of Schiff base ligand and the metal nitrate salts of $\mathrm{Co}(\mathrm{II}), \mathrm{Ni}(\mathrm{II}), \mathrm{Cu}(\mathrm{II})$ or $\mathrm{Zn}(\mathrm{II})$ ions were mixed in a $1: 1$ or $1: 2(\mathrm{~L}: \mathrm{M})$ molar ratio in the preparation of all complexes, the resulting solutions were stirred for about 1 hour, then refluxed on a hot plate from 6 to 8 hours. The solid complexes which separated out on hot were filtered off after cooling to room temperature, washed with small amounts of bidistilled water, diethylether and finally dried in vaccum desiccator over anhydrous $\mathrm{CaCl}_{2}$. All of the complexes prepared were stable at room temperature, non-hygroscopic, insoluble in common organic solvents except DMF.

\subsection{Preparation of Mixed Ligand Complexes}

An ethanolic solution of the metal salt was added gradually to an ethanolic solution of the ligand in the molar ratio 1:1 (L: M). The resulting solutionswere stirred for one hour, then an ethanolic solution of 8-hydroxyquinoline (8HQ) or 1,10 phenanthroline (1, 10-phen.) was added to the previous solution in the molar ratio $1: 1$ (8-HQ or 1, 10-phen: $\mathrm{M})$, the solutions were continuously stirred for 10 hours. The solid complexes which separated out on stirring were filtered off, washed with hot ethanol then diethyl ether and finally dried in vacuum desiccator over anhydrous $\mathrm{CaCl}_{2}$. All of the complexes prepared were stable at room temperature, nonhygroscopic, insoluble in common organic solvents except DMF.

\subsection{Preparation of Nano Cu-Schiff Base Complex}

The copper nanoparticles were prepared using several methods such as thermal reduction, metal vapor synthesis, radiation methods, microemulsion techniques, laser ablation, mechanical attrition, polyol method, thermal decomposition and chemical reduction [30-31]. Among these methods, the reduction method was the most popular one because of the simplicity of its device and technical process. In the chemical reduction technique, a copper salt was reduced by a reducing agent such as sodium borohydride, hydrazine $\left(\mathrm{N}_{2} \mathrm{H}_{4}\right)$, ascorbate or isopropyl alcohol with cetyltrimethylammonium bromide (CTAB) [32-33]. In this work, the nano compounds were prepared by chemical reduction method using isopropyl alcohol with cetyltrimethylammonium bromide (CTAB) as reducing agent.

Nano $\mathrm{Cu}$ - Schiff base complex was synthesized according to Athwale et al [34]. by adding $4 \mathrm{ml}$ of $0.01 \mathrm{M}$ ethanolic solution of Schiff base ligand (HL) drop wise to dry clean beaker contains a mixture of $40 \mathrm{ml}$ CTAB $\left(1 \times 10^{-3} \mathrm{M}\right)$ with 4 $\mathrm{ml}$ copper nitrate $(0.01 \mathrm{M})$ in ethanolic solution. The reaction mixture was stirred on a magnetic stir plate about 4 hours. Leave the reaction mixture few days. The solution will precipitate forming nano $\mathrm{Cu}$-Schiff base complex giving characteristic golden colour as shown in the following image Fig. 2

The nano-structure was characterized by the electronic and ESR spectra, in addition to scanning electron microscopy
(SEM), Fig. 3. The SEM picture of the nano-Cu-Schiff base complex showed a small particle size with a nano feature products. The particles size of nano complex was calculated by smile view program, which gave $(39-96) \mathrm{nm}$ range.

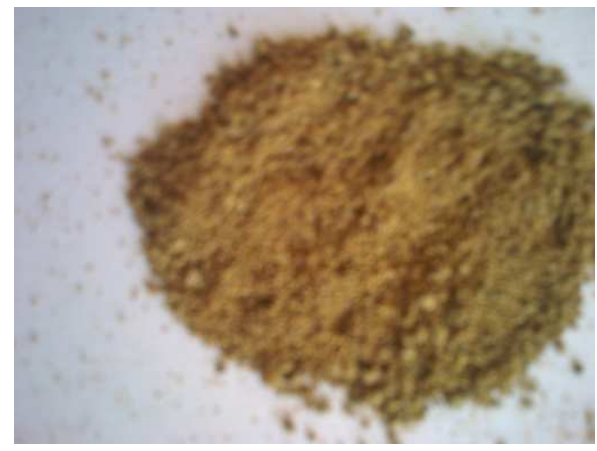

Fig. 2. Image of nano Cu-Schiff base complex

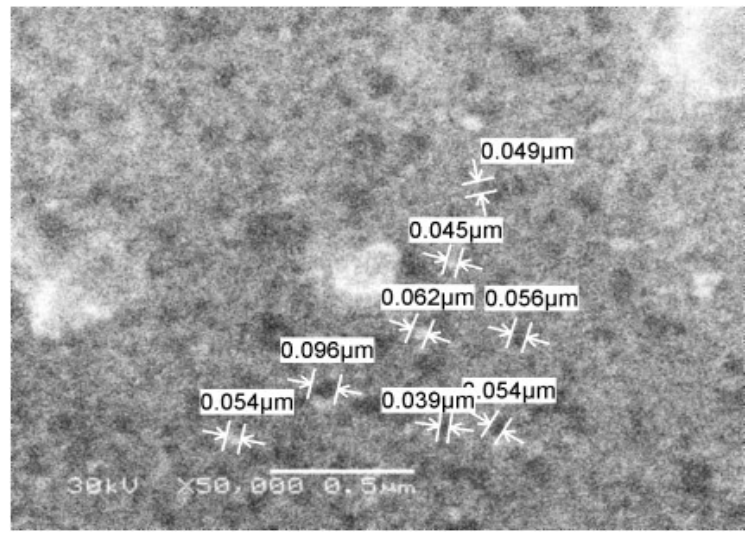

Fig. 3. SEM of nano Cu-Schiff base complex

\section{Results and discussion}

\subsection{Elemental Analysis and Molar Conductance of Solid Complexes}

On the basis of elemental analysis, the metal complexes of HL ligand under investigation were assigned to posses the compositions and molecular formulae listed in Table 1. The analytical data of the isolated solid complexes were in good agreement with the proposed structures. The result of elemental analysis of the solid complexes indicated that the metal ions reacted with the ligand in molar ratios 1: 2 (M: L) for complexes $1,4,7,10$. The results reveal that the ligand act as bidentate towards the metal ions via the azomethine $-\mathrm{N}$ atom and phenolic $-\mathrm{O}$ atom. The chemical composition of the mixed ligand complexes under investigation (HL) and 8hydroxyquinoline (8-HQ) or 1, 10 Phenanthroline (1,10 phen) with $\mathrm{Co}(\mathrm{II}), \mathrm{Ni}(\mathrm{II}), \mathrm{Cu}(\mathrm{II})$ and $\mathrm{Zn}(\mathrm{II})$ ions were determined from the elemental analysis results which collected in Table 1 . The results of the elemental analysis indicated that the metal ions reacted with the ligands (HL) and 8hydroxyquinoline (8-HQ) or 1, 10 Phenanthroline in the molar ratios 1: 1: 1 (M: L: 8-HQ or 1,10 phen) for the complexes $2,3,5,6,8,9,11$ and 12 .The results reveal that the 
Schiff base ligand act as bidentate towards the metal ions via the azomethine $-\mathrm{N}$ atom and phenolic $-\mathrm{O}$ atom. 8-HQ acts as bidentate towards the metal ions via quinoline $-\mathrm{N}$ and hydroxyl $-\mathrm{O}$ atoms in none and deprotanated form.1, 10 phen acts as bidentate towards the metal ions via two phenanthroline $-\mathrm{N}$ atom. The result of elemental analysis also showed that most of the prepared complexes have one or more $\mathrm{H}_{2} \mathrm{O}$ or EtOH molecule associated with the complex which are not removed by static vaccum for six hours at room temperature. The molar conductance values $\left(\Omega \mathrm{ohm}^{-1}\right.$ $\mathrm{cm}^{2} \mathrm{~mol}^{-1}$ ) of the metal complexes were collected in Table (1). All solid complexes have $\Omega_{\mathrm{m}}$ values in the range 6.64-19.01 $\mathrm{ohm}^{-1} \mathrm{~cm}^{2} \mathrm{~mol}^{-1}$ which fall within the range of non electrolytes. This indicates that all these complexes are neutral [35].

Table 1. Analytical and physical data of the metal complexes of the ligand $H L$

\begin{tabular}{|c|c|c|c|c|c|c|c|c|c|}
\hline \multirow{2}{*}{ Compound } & \multirow{2}{*}{ color } & \multirow{2}{*}{$\begin{array}{l}\text { M.P. } \\
\text { C }\end{array}$} & \multirow{2}{*}{ M.Wt gm } & \multicolumn{5}{|c|}{ Analysis (calc. \%) Found \% } & \multirow{2}{*}{$\begin{array}{l}\Omega \mathrm{Ohm}^{-1} \\
\mathrm{Cm}^{2} \mathrm{~mol}^{-1}\end{array}$} \\
\hline & & & & $\% \mathrm{C}$ & $\% \mathrm{H}$ & $\% \mathbf{N}$ & $\% \mathrm{~S}$ & $\% \mathrm{M}$ & \\
\hline$\left[\mathrm{Co}(\mathrm{L})_{2}\left(\mathrm{H}_{2} \mathrm{O}\right) 2\right] 4 \mathrm{H}_{2} \mathrm{O}$ & orange & $>300$ & 1073 & $\begin{array}{l}55.62 \\
(55.92)\end{array}$ & $\begin{array}{l}4.47 \\
(4.29)\end{array}$ & $\begin{array}{l}9.50 \\
(10.44)\end{array}$ & $\begin{array}{l}5.26 \\
(5.96)\end{array}$ & $\begin{array}{l}5.90 \\
(5.49)\end{array}$ & 17.51 \\
\hline$\left[\mathrm{Co}(\mathrm{L})(\mathrm{Phen})\left(\mathrm{H}_{2} \mathrm{O}\right) \mathrm{NO}_{3}\right]$ & Reddish brown & $>300$ & 772 & $\begin{array}{l}58.08 \\
(57.51)\end{array}$ & $\begin{array}{l}3.62 \\
(3.32)\end{array}$ & $\begin{array}{l}11.70 \\
(12.69)\end{array}$ & $\begin{array}{l}3.2 \\
(4.1)\end{array}$ & $\begin{array}{l}8.26 \\
(7.64)\end{array}$ & 11.49 \\
\hline$\left[\mathrm{Co}(\mathrm{L})(\mathrm{HQ})\left(\mathrm{H}_{2} \mathrm{O}\right) 2\right] \mathrm{H}_{2} \mathrm{O}$ & Pale brown & $>300$ & 710 & $\begin{array}{l}57.68 \\
(57.4)\end{array}$ & $\begin{array}{l}3.91 \\
(4.08)\end{array}$ & $\begin{array}{l}10.7 \\
(9.9)\end{array}$ & $\begin{array}{l}3.6 \\
(4.5)\end{array}$ & $\begin{array}{l}7.7 \\
(8.3)\end{array}$ & 17 \\
\hline$\left[\mathrm{Ni}(\mathrm{L})_{2}\left(\mathrm{H}_{2} \mathrm{O}\right) 2\right] \mathrm{H}_{2} \mathrm{O}$ & brown & $>300$ & 1018.7 & $\begin{array}{l}58.18 \\
(58.9)\end{array}$ & $\begin{array}{l}3.75 \\
(3.93)\end{array}$ & $\begin{array}{l}10.64 \\
(10.99)\end{array}$ & $\begin{array}{l}6.10 \\
(6.28)\end{array}$ & $\begin{array}{l}5.88 \\
(5.76)\end{array}$ & 18.52 \\
\hline$\left[\mathrm{Ni}(\mathrm{L})(\mathrm{Phen})\left(\mathrm{H}_{2} \mathrm{O}\right) \mathrm{NO}_{3}\right]$ & brown & $>300$ & 754 & $\begin{array}{l}59.19 \\
(58.52)\end{array}$ & $\begin{array}{l}3.88 \\
(3.71)\end{array}$ & $\begin{array}{l}13.0 \\
(12.99)\end{array}$ & $\begin{array}{l}5.13 \\
(4.24)\end{array}$ & $\begin{array}{l}7.26 \\
(7.82)\end{array}$ & 17.26 \\
\hline$\left[\mathrm{Ni}(\mathrm{L})(\mathrm{HQ})\left(\mathrm{H}_{2} \mathrm{O}\right) 2\right] \mathrm{EtOH}$ & brown & $>300$ & 737.86 & $\begin{array}{l}57.96 \\
(58.55)\end{array}$ & $\begin{array}{l}4.15 \\
(4.47)\end{array}$ & $\begin{array}{l}9.24 \\
(9.49)\end{array}$ & $\begin{array}{l}4.24 \\
(4.34)\end{array}$ & $\begin{array}{l}9.7 \\
(7.95)\end{array}$ & 19.0 \\
\hline$\left[\mathrm{Cu} .(\mathrm{L})_{2}\right] 2 \mathrm{EtOH}$ & brown & $>300$ & 1061.5 & $\begin{array}{l}61.73 \\
(61.5)\end{array}$ & $\begin{array}{l}3.7 \\
(4.33)\end{array}$ & $\begin{array}{l}9.48 \\
(10.5)\end{array}$ & $\begin{array}{l}5.6 \\
(6.0)\end{array}$ & $\begin{array}{l}6.5 \\
(5.93)\end{array}$ & 13.5 \\
\hline$\left[\mathrm{Cu}(\mathrm{L})(\mathrm{Phen})\left(\mathrm{H}_{2} \mathrm{O}\right) \mathrm{NO}_{3}\right]$ EtOH & green & 251 & 804.5 & $\begin{array}{l}58.82 \\
(58.17)\end{array}$ & $\begin{array}{l}3.98 \\
(3.85)\end{array}$ & $\begin{array}{l}11.18 \\
(12.18)\end{array}$ & $\begin{array}{l}4.26 \\
(3.98)\end{array}$ & $\begin{array}{l}8.70 \\
(7.9)\end{array}$ & 18.83 \\
\hline$[\mathrm{Cu} . \mathrm{L}(\mathrm{HQ})] \cdot \mathrm{EtOH}$ & brown & $>300$ & 706.66 & $\begin{array}{l}61.72 \\
(61.13)\end{array}$ & $\begin{array}{l}3.94 \\
(4.1)\end{array}$ & $\begin{array}{l}9.33 \\
(9.91)\end{array}$ & $\begin{array}{l}4.71 \\
(4.53)\end{array}$ & $\begin{array}{l}9.00 \\
(8.98)\end{array}$ & 9.51 \\
\hline$\left[\mathrm{Zn}(\mathrm{L})_{2}\right] 6 \mathrm{H}_{2} \mathrm{O}$ & orange & $>300$ & 1079 & $\begin{array}{l}55.39 \\
(55.6)\end{array}$ & $\begin{array}{l}3.65 \\
(3.55)\end{array}$ & $\begin{array}{l}10.22 \\
(10.27)\end{array}$ & $\begin{array}{l}5.50 \\
(5.8)\end{array}$ & $\begin{array}{l}6.70 \\
(6.02)\end{array}$ & 17.8 \\
\hline$\left[\mathrm{Zn}(\mathrm{L})(\mathrm{Phen})\left(\mathrm{H}_{2} \mathrm{O}\right) \mathrm{NO}_{3}\right]$ & orange & $>300$ & 776 & $\begin{array}{l}58.09 \\
(57.21)\end{array}$ & $\begin{array}{l}3.34 \\
(3.60)\end{array}$ & $\begin{array}{l}11.64 \\
(12.6)\end{array}$ & $\begin{array}{l}4.94 \\
(4.12)\end{array}$ & $\begin{array}{l}9.30 \\
(8.38)\end{array}$ & 7.78 \\
\hline$[\mathrm{Zn}(\mathrm{L})(\mathrm{HQ})] 2 \mathrm{H}_{2} \mathrm{O}$ & orange & 238 & 680 & $\begin{array}{l}59.85 \\
(58.45)\end{array}$ & $\begin{array}{l}3.63 \\
(3.86)\end{array}$ & $\begin{array}{l}10.36 \\
(10.03)\end{array}$ & $\begin{array}{l}4.39 \\
(4.58)\end{array}$ & $\begin{array}{l}9.80 \\
(9.56)\end{array}$ & 6.64 \\
\hline
\end{tabular}

\subsection{IR Spectral Studies}

The mode of bonding of the Schiff base complexes was elucidated by investigating the IR spectra of the metal complexes as compared with that of the free Schiff base. The IR spectra of most solid complexes exhibit a broad band within the range $3361-3442 \mathrm{~cm}^{1}$, which is attributed to the $v_{\mathrm{OH}}$ of water and/or EtOH molecules associated with the complex. Also, the existence of the new bands at 617- 695 $\mathrm{cm}^{-1}$ for complexes $1,2,3,4,5,6,8$ and 11 is attributed to $\mathrm{pH}_{2} \mathrm{O}$ of coordinated water molecules, indicating the presence of coordinated water molecules in the metal ion complexes. The disappearance of $v \mathrm{OH}$ phenolic in the IR spectra of all solid complexes under investigation which are observed at 3355 $\mathrm{cm}^{-1}$ in the IR of the free ligand, denotes that proton displacement from the phenolic $v \mathrm{OH}$ group takes through the metal ion. This is confirmed by the existence of new bands at 500- $568 \mathrm{~cm}^{-1}$ in the IR spectra of all metal chelates which are absent in the IR spectra of the free ligand which could be assigned to $v \mathrm{M}-\mathrm{O}$ bonds. The $v \mathrm{C}=\mathrm{N}$ band observed at 1624 $\mathrm{cm}^{-1}$ in the IR of the free ligand is shifted to lower wave numbers by $8-12 \mathrm{~cm}^{-1}$ in the IR spectra of all metal complexes under investigation, indicating the coordination of the azomethine nitrogen atoms to the metal ions, which is supported by the existence of new bands in the IR spectra of all metal complexes at 419- $498 \mathrm{~cm}^{-1}$, these bands would be assigned to $v \mathrm{M}-\mathrm{N}$ bonds [36]. The complexes 2,5,8 and 11 show new bands at $1312-1344 \mathrm{~cm}^{-1}$ due to $\mathrm{NO}_{3}{ }^{-}$ion which support the coordinated nature of the $\mathrm{NO}_{3}{ }^{-}$ion [36]. The IR spectra of free ligand HL shows band at $3066 \mathrm{~cm}^{-1}$ indicating that the presence of $v_{\mathrm{NH}}$ group, this band lies as it is in all solid complexes under investigation, indicating that the $\mathrm{N}$ atom of $\mathrm{NH}$ group dos not participate in complex formation. Also, the $\mathrm{SO}_{2}$ group modes of the ligand appears two bands at $1135 \mathrm{and} 1089 \mathrm{~cm}^{-1}$ assigned to $v_{\text {asm }}\left(\mathrm{SO}_{2}\right)$ and $v_{\text {sym }}\left(\mathrm{SO}_{2}\right)$, respectively .These bands appear also at its same position in case of all solid complexes under investigation which indicate that the $\mathrm{SO}_{2}$ group dos not coordinated to metal ion.

\section{3. ${ }^{1}$ H-NMR Spectral Studies}

${ }^{1} \mathrm{H}-\mathrm{NMR}$ spectra of Schiff base ligand and its $\mathrm{Zn}$ (II) complex were recorded in DMSO-d6. The signal at $\delta(8.41)$ $(\mathrm{s}, 1 \mathrm{H})$ was assigned to the azomethine proton $(-\mathrm{N}=\mathrm{CH}-)$ of the Schiff base (HL) shifted downfield in the region of $\delta$ $(8.65)(\mathrm{s}, 1 \mathrm{H})$, supporting the coordination of the ' $\mathrm{N}$ ' of the $\mathrm{N}=\mathrm{CH}$ - group with the metal ion. The peak due to hydroxyl proton originally present at $\delta \sim 12.11-12.47 \mathrm{ppm}$ in free Schiff base ligand is completely absent from the spectra of $\mathrm{Zn}$ (II) complex suggesting the bonding through hydroxyl 
oxygen atom. The appearance of a peak at signals at 8.9-9.6 $(\mathrm{s}, \mathrm{H}, \mathrm{NH}) \mathrm{ppm}$ as a broad singlet could be assigned to $\mathrm{N}-\mathrm{H}$ group for both the ligand and its $\mathrm{Zn}(\mathrm{II})$ complex respectively, suggesting the non-involvement of $\mathrm{N}-\mathrm{H}$ group in bond formation.

\subsection{Mass Spectral Studies}

The FAB mass spectrum of the $\mathrm{Cu}(\mathrm{II})$ complex showed a molecular ion peak at $\mathrm{m} / \mathrm{z} 1061$, which is the same as that of the molecular weight of the complex. This supports the suggested structure for the complex

\subsection{Thermo Gravimetric Analyses}

The aim of the present thermal gravimetric analysis (TGA) study is to obtain information concerning to the thermal stability of the investigated chelates and to define whether the water or solvent molecules are inside or outside the coordination sphere [22].

The application of derivative plots showing the rate of mass change as a function of temperature or time (derivative thermogravimetry, DTG) are useful in attempting to resolve overlapping processes and to determine the point at which the mass loss is most significant, also it useful for some methods of calculation the thermodynamic parameters [35].

The TGA-DTG curves of some metal complexes, namely $\mathrm{Co}(\mathrm{II}), \mathrm{Ni}(\mathrm{II})$ and $\mathrm{Cu}(\mathrm{II})$ complexes were recorded from ambient temperature up to $800{ }^{\circ} \mathrm{C}$ under $\mathrm{N}_{2}$ gas flow at heating rate of $10^{\circ} \mathrm{C} / \mathrm{min}$ as shown in Fig.4.

For the $\mathrm{Co}(\mathrm{II})$ complex, a mass loss occurred within the temperature range $42-126^{\circ}$ Ccorresponding to the loss of $3.2 \%$ (Calcd 3.3\%) for two molecules of lattice water and at the temperature range $127-297{ }^{\circ} \mathrm{C}$ another loss of $6.1 \%$ (Calcd. $6.7 \%$ ) for another two lattice and two coordinate water molecules. In the temperature range $298-356{ }^{\circ} \mathrm{C}$ a mass loss of $4.6 \%$ (Calcd. $5.0 \%$ ) corresponding to two $\mathrm{HCN}$ molecules. At the temperature $356.9-473{ }^{\circ} \mathrm{C}$ a loss of $36.5 \%$ (Calcd. $37.1 \%$ ) for $\mathrm{C}_{24} \mathrm{H}_{16} \mathrm{~N}_{3} \mathrm{~S}$ as apart of ligand decomposition. At higher temperature range $473.9-789{ }^{\circ} \mathrm{C}$ a loss of $36.3 \%$ (Calcd. 37.1) corresponding to $\mathrm{C}_{24} \mathrm{H}_{16} \mathrm{~N}_{3} \mathrm{~S}$ as another part of the compound, then it forms $\mathrm{CoO}$.

For the Ni (II) complex, a mass loss occurred within the temperature range $41.5-231.7^{\circ} \mathrm{C}$, corresponding to the loss of 3.02 (calc.3.3\%) for two water molecules (Lattice and coordinated) and at the temperature range $232.2-369{ }^{\circ} \mathrm{C}$, another loss of 23.8 (calc.23.6) \% for another one coordinate water with $2 \mathrm{HCN}$ and $\mathrm{C}_{8} \mathrm{H}_{6} \mathrm{~N}_{3} \mathrm{SO}_{2}$ as apart from the ligand. At higher temperature range $397-778{ }^{\circ} \mathrm{C}$ a loss of $59 \%$ (Calcd. 58\%) corresponding to $\mathrm{C}_{43} \mathrm{H}_{28} \mathrm{~N}_{3} \mathrm{SO}_{4}$ decomposition of the compound then it gives $\mathrm{NiO}$.

For the $\mathrm{Cu}$ (II) complex, a mass loss occurred within the temperature range $34-220^{\circ}$ corresponding to the loss of $20.4 \%$ (calc. $20.9 \%$ ) for two molecules of lattice ethanol with $\mathrm{C}_{8} \mathrm{H}_{6} \mathrm{~N}_{2}$. At the temperature range $225-300{ }^{\circ} \mathrm{C}$ another loss of $24.5 \%$ (calc. 25.6 ) \% for $\mathrm{C}_{8} \mathrm{H}_{7} \mathrm{~N}_{3} \mathrm{~S}_{2} \mathrm{O}_{4}$. In the temperature range $305-400{ }^{\circ} \mathrm{C}$ a mass loss of $9.2 \%$ (calc.9.8) \% corresponding to $\mathrm{C}_{7} \mathrm{H}_{7} \mathrm{~N}$. At higher temperature range 400.5
- $799^{\circ} \mathrm{C}$ a loss of $35.8 \% \quad(35.8 \%)$ corresponding to $\mathrm{C}_{27} \mathrm{H}_{13} \mathrm{~N}_{2} \mathrm{O}_{2}$ from the compound, then it forms $\mathrm{CuO}$.

From the decomposition temperatures the thermal stability of the $\mathrm{Co}(\mathrm{II}), \mathrm{Ni}(\mathrm{II})$ and $\mathrm{Cu}$ (II) complexes was deduced in the order $\mathrm{Cu}$ (II) $>\mathrm{Co}$ (II) $>\mathrm{Ni}$ (II).

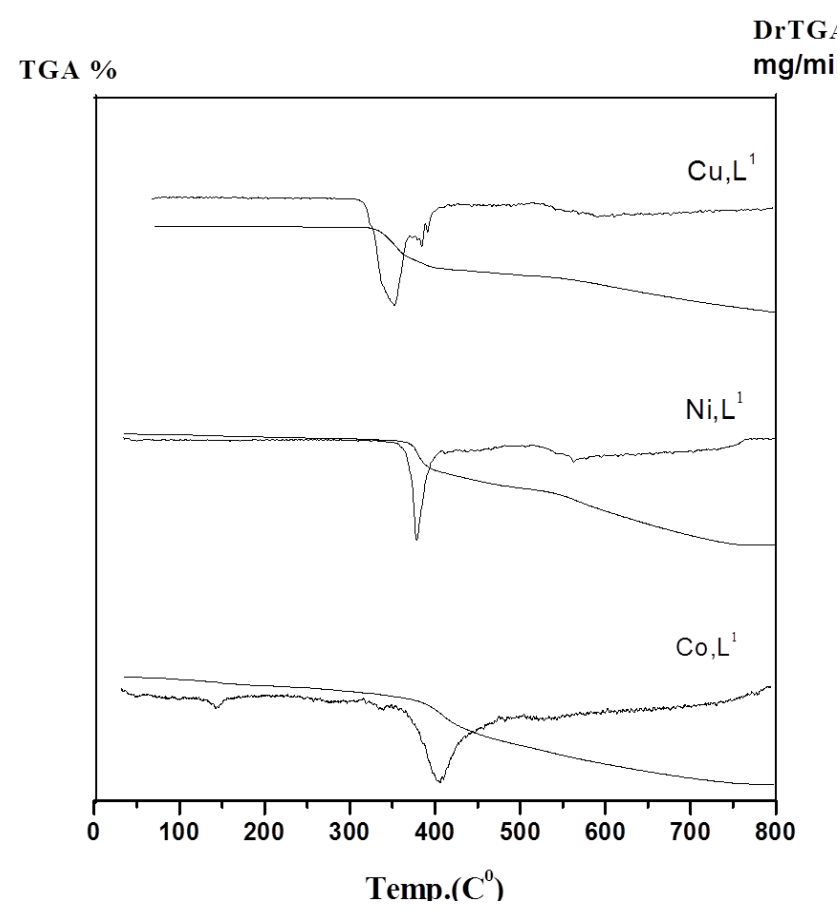

Fig. 4.TGA - DrTGA curves of Co (11), Ni(11) and Cu(11) complexes

The order, $\mathrm{n}$ and activation energy, $\mathrm{E}^{*}$ of the decomposition steps for $\mathrm{Co}(\mathrm{II}), \mathrm{Ni}(\mathrm{II})$ and $\mathrm{Cu}$ (II) complexes were determined from TGA results using the Coats-Redfern equation [37]:

$$
\begin{array}{ll}
\ln \left[\left\{1-(1-\alpha)^{1-n}\right\} /(1-n) T^{2}\right]=(M / T)+B & \text { for } n \neq 1 \\
\ln \left[\{-\ln (1-\alpha)\} / T^{2}\right]=(M / T)+B & \text { for } n=1
\end{array}
$$

Where $\mathrm{M}=-\mathrm{E}^{*} / \mathrm{R}$ and $\mathrm{B}=\ln \left(\mathrm{AR} / \Phi \mathrm{E}^{*}\right) ; \mathrm{E}^{*}, \mathrm{R}, \mathrm{A}$ and $\Phi$ are the activation energy, gas constant, pre-exponential factor and heating rate, respectively, $\mathrm{n}=0,0.33,0.5,0.66,1$

The other thermo kinetic parameters $\left(\Delta \mathrm{H}^{*}, \Delta \mathrm{S}^{*}, \Delta \mathrm{G}^{*}\right)$ were calculated. The order (n) and thermo kinetic parameters of the decomposition steps for the chosen complexes are listed in Table 2. From the obtained data, the following remarks can be pointed out:

1-The $\Delta S^{*}$ values for complexes were found to be positive. This indicates that the activated complex is less ordered than the reactants and / or the reactions are fast [38].

2-The values of $\Delta \mathrm{G}^{*}$ increase significantly for the subsequently decomposition stages due to increasing the values of $T \Delta S^{*}$ from one step to another which override the values of $\Delta \mathrm{H}^{*}$. This increase reflects that the rate of removal of the subsequent ligand will be lower than that of the precedent ligand [39]. This may be attributed to the structural rigidity of the remaining complex after the expulsion of one and more ligands, as compared with the precedent complex, which requires more energy for its rearrangement before 
undergoing any compositional change.

3-The positive values of $\Delta \mathrm{H}^{*}$ means that the

decomposition processes are endothermic.

Table 2. Thermodynamic activation parameters of the thermal decomposition of some complexes of the ligand HL

\begin{tabular}{|c|c|c|c|c|c|c|c|c|}
\hline \multicolumn{9}{|c|}{ Thermodynamic activation parameters } \\
\hline Complex & step & $\mathbf{n}$ & $\mathbf{R}$ & $\begin{array}{l}\mathbf{E}^{*} \\
\left(\mathrm{KJmol}^{-1}\right)\end{array}$ & $\begin{array}{l}\Delta \mathrm{H}^{*} \\
\left(\mathrm{KJmol}^{-1}\right)\end{array}$ & $\begin{array}{l}\mathrm{A} \\
\left(\mathrm{S}^{-1}\right)\end{array}$ & $\begin{array}{l}\Delta \mathbf{S}^{*} \\
\left(\mathrm{KJmol}^{-1} \mathbf{K}^{-1}\right)\end{array}$ & $\begin{array}{l}\Delta \mathrm{G}^{*} \\
\left(\mathrm{KJmol}^{-1}\right)\end{array}$ \\
\hline \multirow{5}{*}[\mathrm{Co}(\mathrm{L}^{1})_{2}2\mathrm{H}_{2}\mathrm{O}]{$4 \mathrm{H}_{2} \mathrm{O}$} & $1^{\text {st }}$ & 1 & 0.9933 & 0.03213 & 0.909300 & 3.52055 & 0.06348 & 6.28267 \\
\hline & $2^{\text {nd }}$ & 0 & 0.9974 & 0.019599 & 1.98643 & 0.00443 & 0.125262 & 28.25 \\
\hline & $3^{\text {rd }}$ & 0.33 & 0.9995 & 0.119896 & 2.645505 & $47.88 \times 10^{5}$ & 0.04492 & 12.305 \\
\hline & $4^{\text {th }}$ & 0.66 & 0.9967 & 0.21054 & 3.23769 & $3.84 \times 10^{12}$ & 0.1560 & 61.5223 \\
\hline & $5^{\text {th }}$ & 1 & 0.9977 & 0.05252 & 4.84330 & 0.0874 & 0.10788 & 58.71944 \\
\hline \multirow{3}{*}[\mathrm{Ni}(\mathrm{L}^{1})_{2}\cdot2\mathrm{H}_{2}\mathrm{O}]{$\mathrm{H}_{2} \mathrm{O}$} & $1^{\text {st }}$ & 1 & 0.993 & 0.02432 & 3.36266 & 0.12256 & 0.102025 & 38.2206 \\
\hline & $2^{\text {nd }}$ & 0.33 & 0.9931 & 0.07835 & 5.3323 & 754.348 & 0.03341 & 16.4232 \\
\hline & $3^{\text {rd }}$ & 0.33 & 0.9943 & 0.01299 & 4.85384 & 0.164331 & 0.164331 & 91.3883 \\
\hline \multirow{4}{*}[\mathrm{Cu}(\mathrm{L}^{1})_{2}]{$2 \mathrm{EtOH}$} & $1^{\text {st }}$ & 0.5 & 0.9939 & 0.06485 & 2.6211 & $14.09 \times 10^{5}$ & 0.05414 & 14.8783 \\
\hline & $2^{\text {nd }}$ & 0.33 & 0.9777 & 0.010305 & 5.1413 & $1.40 \times 10^{-5}$ & 0.18092 & 107.0189 \\
\hline & $3^{\text {rd }}$ & 0.66 & 0.9947 & 0.27533 & 5.15524 & $4.8 \times 10^{-18}$ & 0.2690 & 170.637 \\
\hline & $4^{\text {th }}$ & 1 & 0.9957 & 0.04994 & 7.42057 & 0.040427 & 0.11781 & 98.4928 \\
\hline
\end{tabular}

\subsection{Magnetic Properties}

The magnetic moment values obtained at room temperature were listed in Table 3. The magnetic measurements for all $\mathrm{Co}(\mathrm{II})$ and $\mathrm{Ni}(\mathrm{II})$ complexes showed magnetic moment values of 4.3-5.3 and 2.88-3.6 BM respectively, suggesting consistency with their octahedral environment [35]. The $\mathrm{Cu}(\mathrm{II})$ complexes 7,8 and 9 showed the magnetic moment values of 2.05 and 2,2.1 BM respectively expected for one unpaired electron, which offers the possibility of a distorted octahedral or square planner geometry[39].The measured effective magnetic values for the $\mathrm{Cu}$-complexes, some what higher than spin-only value . Such divergence is not uncommon $\mathrm{Cu}$ (II) complexes due to mixing-in of some angular momentum from the closely lying excited state via spin-orbit coupling[40].

\subsection{Electronic Spectral Studies}

The electronic spectra of the $\mathrm{Co}(\mathrm{II}), \mathrm{Ni}(\mathrm{II})$, and $\mathrm{Cu}(\mathrm{II})$ complexes were recorded in freshly prepared DMF solution $\left(10^{-3} \mathrm{M}\right)$ at room temperature and the spectral data were presented in Table 3. The electronic absorption spectra of the $\mathrm{Co}$ (II) complexes namely,1,2 and 3show bands at 658, 665 and $650 \mathrm{~nm}$ respectively corresponding to ${ }^{4} \mathrm{~T}_{1 \mathrm{~g}}(\mathrm{~F}) \rightarrow{ }^{4} \mathrm{~A}_{2 \mathrm{~g}}(\mathrm{P})$ and ${ }^{4} \mathrm{~T}_{1 \mathrm{~g}}(\mathrm{~F}) \rightarrow{ }^{4} \mathrm{~T}_{1 \mathrm{~g}}(\mathrm{P})$ transitions indicating octahedral structure[41].

The Ni(II) complexes 4, 5, 6 exhibited 2 absorption bands, at $630-645$ and $740-768 \mathrm{~nm}$ ranges, assignable to $3 \mathrm{~A}_{2} g(\mathrm{~F})$ $\rightarrow 3 \mathrm{~T}_{1} g(\mathrm{~F})\left(v_{2}\right)$ and $3 \mathrm{~A}_{2} g(\mathrm{~F}) \rightarrow 3 \mathrm{~T}_{1} g(\mathrm{P})\left(v_{3}\right)$ transitions, respectively, in an octahedral environment[42]. The $\mathrm{Cu}(\mathrm{II})$ complexes7,8 and 9 exhibited a single broad asymmetric band in the region of 630-658 $\mathrm{nm}$ ranges corresponding to ${ }^{2} \mathrm{E} g \rightarrow{ }^{2} \mathrm{~T}_{2} g$. The broadness of the band may have been due to dynamic Jahn-Teller distortion. All of these data suggested a distorted octahedral geometry around the $\mathrm{Cu}(\mathrm{II})$ ion in case of complex 8 or distorted octahedral leads to square planner geometry around the $\mathrm{Cu}$ (II) ion in case of complexes 7 and 9 [42]. As expected, the electronic spectra of the $\mathrm{Zn}$ (II) complexes do not furnish any relevant data towards stereochemistry, but on the basis of analytical, conductance, and infrared spectral data, a square planner geometries were proposed for the complexes 10 and 12 of the $\mathrm{Zn}(\mathrm{II})$ complexes and octahedral for the complex 11.

In case of $\mathrm{Cu}$-nano complex, the mole ratio 1:30 provided an absorption peak at $560 \mathrm{~nm}$ (Table 4) with no residual absorption at $800 \mathrm{~nm}$ (corresponding to $\mathrm{Cu}^{+2}$ ions), and no shoulder at $630 \mathrm{~nm}$ which disappeared at later stages of addition. The latter absorption band may due to the formation of a transient complex between terminal ammonium ion of CTAB and $\mathrm{Cu}^{+2}$ ions in IPA which may be converting to $\mathrm{Cu}^{0}$ (peak at $560 \mathrm{~nm}$ ) at latter stages, confirming formation of pure spherical copper particles [34].Also, this change is related to the complex formation between Schiff base ligand (HNMABSQ) and colloidal Cu-nanoparticles.

Table 3. $U V$ - visible spectra, $g_{\text {eff }}$ and Magnetic Moment data of the complexes

\begin{tabular}{|c|c|c|c|c|c|}
\hline \multirow{2}{*}{ No. } & \multirow{2}{*}{ complexes } & $\lambda_{\max .}(\mathrm{nm})$ & \multirow{2}{*}{ d-d assignment } & \multirow[t]{2}{*}{$\mu_{\text {eff.B.M. }}$} & \multirow[t]{2}{*}{$\mathbf{g}_{\text {eff }}$} \\
\hline & & In DMF solution & & & \\
\hline 1 & {$\left[\mathrm{Co}((\mathrm{HNMABSQ}))_{2}\left(\mathrm{H}_{2} \mathrm{O}\right)_{2}\right] 4 \mathrm{H}_{2} \mathrm{O}$} & 658 & ${ }^{4} \mathrm{~T}_{1 \mathrm{~g}}(\mathrm{~F}) \rightarrow{ }^{4} \mathrm{~A}_{2 \mathrm{~g}}(\mathrm{P}),{ }^{4} \mathrm{~T}_{1 \mathrm{~g}}(\mathrm{~F}) \rightarrow{ }^{4} \mathrm{~T}_{1 \mathrm{~g}}(\mathrm{P})$ & 5.1 & \\
\hline 2 & [Co (HNMABSQ) $\left.(\mathrm{Phen})\left(\mathrm{H}_{2} \mathrm{O}\right)(\mathrm{NO})_{3}\right]$ & 665 & ${ }^{4} \mathrm{~T}_{1 \mathrm{~g}}(\mathrm{~F}) \rightarrow{ }^{4} \mathrm{~A}_{2 \mathrm{~g}}(\mathrm{P}),{ }^{4} \mathrm{~T}_{1 \mathrm{~g}}(\mathrm{~F}) \rightarrow{ }^{4} \mathrm{~T}_{1 \mathrm{~g}}(\mathrm{P})$ & 4.3 & \\
\hline 3 & {$\left[\mathrm{Co}(\mathrm{HNMABSQ})_{2}(\mathrm{HQ})\left(\mathrm{H}_{2} \mathrm{O}\right)_{2}\right] \mathrm{H}_{2} \mathrm{O}$} & 651 & ${ }^{4} \mathrm{~T}_{1 \mathrm{~g}}(\mathrm{~F}) \rightarrow{ }^{4} \mathrm{~A}_{2 \mathrm{~g}}(\mathrm{P}),{ }^{4} \mathrm{~T}_{1 \mathrm{~g}}(\mathrm{~F}) \rightarrow{ }^{4} \mathrm{~T}_{1 \mathrm{~g}}(\mathrm{P})$ & 5.3 & \\
\hline 4 & {$\left[\mathrm{Ni}(\mathrm{HNMABSQ})_{2}\left(\mathrm{H}_{2} \mathrm{O}\right)_{2}\right] . \mathrm{H}_{2} \mathrm{O}$} & 630,740 & ${ }^{3} \mathrm{~A}_{2 \mathrm{~g}} \rightarrow{ }^{3} \mathrm{~T}_{1 \mathrm{~g}}(\mathrm{~F}),{ }^{3} \mathrm{~A}_{2 \mathrm{~g}} \rightarrow{ }^{3} \mathrm{~T}_{1 \mathrm{~g}}(\mathrm{P})$ & 2.8 & \\
\hline 5 & [Ni (HNMABSQ)(Phen) $\left.\left(\mathrm{H}_{2} \mathrm{O}\right) \mathrm{NO}_{3}\right]$ & 640,768 & ${ }^{3} \mathrm{~A}_{2 \mathrm{~g}} \rightarrow{ }^{3} \mathrm{~T}_{1 \mathrm{~g}}(\mathrm{~F}),{ }^{3} \mathrm{~A}_{2 \mathrm{~g}} \rightarrow{ }^{3} \mathrm{~T}_{1 \mathrm{~g}}(\mathrm{P})$ & 3.6 & \\
\hline 6 & $\left.[\mathrm{Ni}(\mathrm{HNMABSQ}))(\mathrm{HQ})\left(\mathrm{H}_{2} \mathrm{O}\right) 2\right] \mathrm{EtOH}$ & 645,763 & ${ }^{3} \mathrm{~A}_{2 \mathrm{~g}} \rightarrow{ }^{3} \mathrm{~T}_{1 \mathrm{~g}}(\mathrm{~F}),{ }^{3} \mathrm{~A}_{2 \mathrm{~g}} \rightarrow{ }^{3} \mathrm{~T}_{1 \mathrm{~g}}(\mathrm{P})$ & 3.3 & \\
\hline 7 & {$\left[\mathrm{Cu}(\mathrm{HNMABSQ})_{2}\right] 2 \mathrm{EtOH}$} & 658 & ${ }^{2} \mathrm{E} g \rightarrow \rightarrow^{2} \mathrm{~T} 2 g$ & 2.05 & 2.1 \\
\hline 8 & {$\left[\mathrm{Cu}(\mathrm{HNMABSQ})(\mathrm{Phen})\left(\mathrm{H}_{2} \mathrm{O}\right) \mathrm{NO}_{3}\right] \mathrm{EtOH}$} & 665 & ${ }^{2} \mathrm{E} g \rightarrow \rightarrow^{2} \mathrm{~T} 2 g$ & 2.0 & 2.35 \\
\hline 9 & [Cu (HNMABSQ) (HQ)].EtOH & 651 & ${ }^{2} \mathrm{E} g \rightarrow{ }^{2} \mathrm{~T} 2 g$ & 2.1 & 2.05 \\
\hline
\end{tabular}




\subsection{ESR Spectra of $\mathrm{Cu}$ (II) Complexes}

ESR spectra of $\mathrm{Cu}$ (II) complexes, and nano $\mathrm{Cu}$ HNMABSQ Complex were recorded at room temperature as shown in Fig. 5. The geff values were calculated and recorded in Table 3. The shape of ESR signals and the $g_{\text {eff }}$ values for $\mathrm{Cu}$ (II) complexes 7, 8 and 9 respectively, indicated square planner for complexes 7 and 9 or distorted octahedral geometries for comlex 8 around $\mathrm{Cu}$ (II) ions in these complexes, where two anisotropic signals were observed. From the observed g-values of the $\mathrm{Cu}$ (II) complexes, it is clear that $\mathrm{g}_{\mathrm{II}}>\mathrm{g} \perp$ which indicates that the unpaired electron is predominantly in the $\mathrm{dx}^{2}-\mathrm{y}^{2}$ orbital [43] giving ${ }^{2} \mathrm{~B}_{1} \mathrm{~g}$ as the ground state. The observed data showed that the $\mathrm{g}_{\text {II }}$ values are $>2.0023$ for complexes and hence the metal-ligand bonding in these complexes is essentially covalent character [44].

In case of nano $\mathrm{Cu}$-Schiff base complex, $\mathrm{X}$ - band ESR spectrum showed four anisotropic lines due to phenoxide of naphthyl moiety $[34,45]$ as seen in Fig 6.

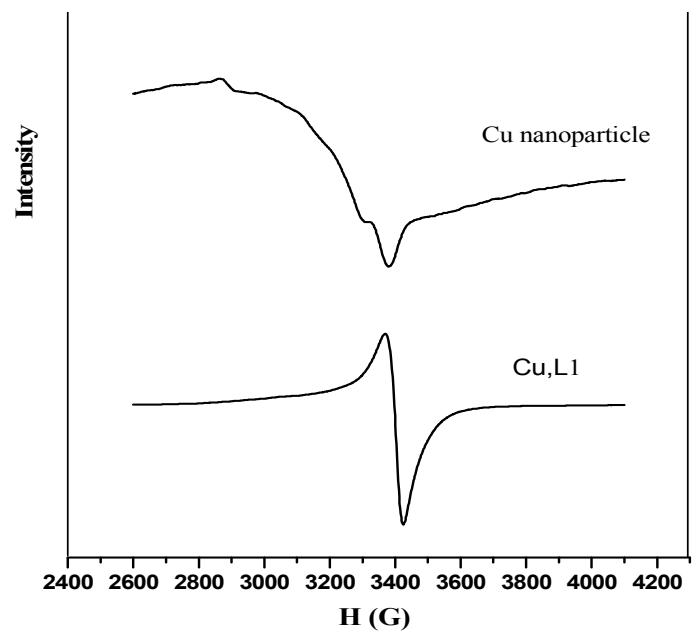

Fig. 5. X-band ESR spectra of $C u, L$ and nano $C u L$ complex

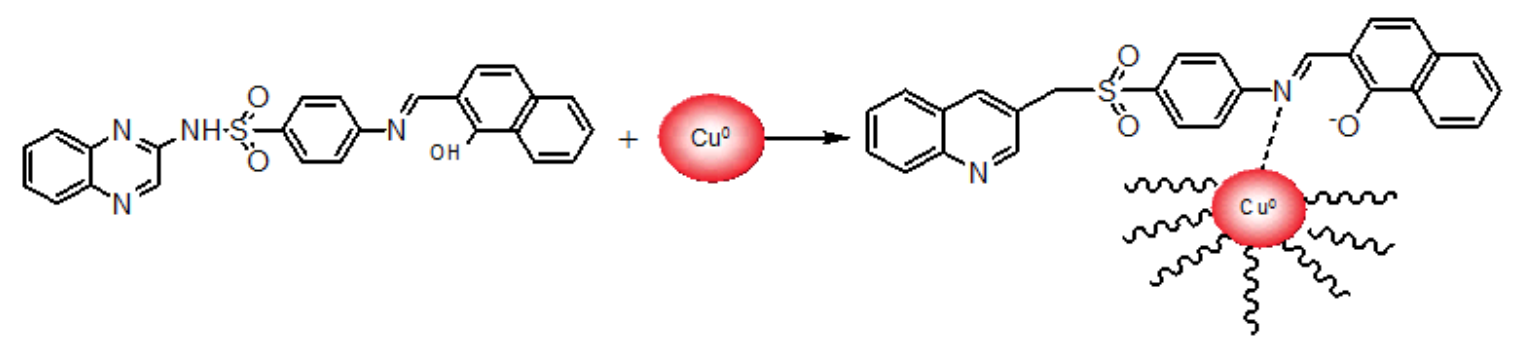

Fig. 6. Mechanism between $H N M A B S Q$ and $\mathrm{Cu}^{0}$

\subsection{D Molecular Modeling Study}

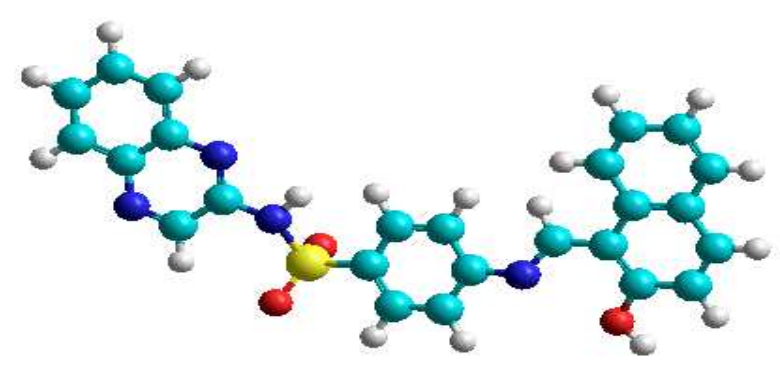

Fig. 7. Modeling structure of ligand $(H L)$

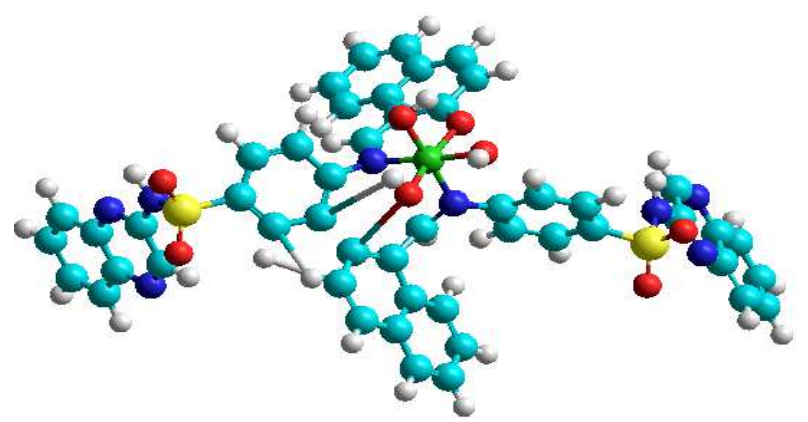

Fig. 8. Modeling structure of Ni (II) complex

3D modeling of the ligand and its metal complexes were studied by PM3 method to confirm the geometry of the ligand and its complexes using Hyperchem 7.52 program
[46-47]. The 3D-optimized molecular structures of the Schiff base ligand and some complexes namely 1, 4, 7 and 10 were shown in Figs 7, 8.

\subsubsection{Molecular Parameters}

The molecular parameters: total energy, binding energy, electronic energy, heat of formation, dipole moment, energy of the lowest occupied molecular orbital ( $\mathrm{E}_{\text {номо }}$ ) and energy of the highest unoccupied molecular orbital $\left(\mathrm{E}_{\mathrm{LUMO}}\right)$ were calculated and represented in Table 4 . Additional parameters, such as separation energy, $\Delta \mathrm{E}$ (the gap between the HOMO and LUMO energy levels, $\left(\mathrm{E}_{\text {gap }}\right)$, electrophilicity index $(\chi)$, chemical potential (pi), absolute hardness ( $)$, absolute softness $(\sigma)$ and additional electronic charge $\left(\Delta \mathrm{N}_{\max }\right)$ were calculated [48] and listed in Table 4.

From the obtained data, we can conclude the following:

a) Absolute hardness $(\eta)$ and softness $(\sigma)$ are important properties to measure the molecular stability and reactivity. A hard molecular has a large energy gap and a soft molecule has a small energy gap. Soft molecules are more reactive than hard ones because they could easily offer electrons to an acceptor. In a complex formation system, the ligand acts as Lewis base while the metal ion acts as Lewis acid. Metal ions are soft acids and thus soft base ligands are most effective for complex formation [47-48]. Accordingly, it is concluded that the ligand $\mathrm{HL}$ with proper $\sigma$ values has a good tendency to 
chelae metal ions effectively.

b) The reactivity index measures the stabilization in energy when a system acquires an additional electronic charge $\left(\Delta \mathrm{N}_{\max }\right)$ from the environment. electrophilicity index $(\chi)$ is a positive, definite quantity and the direction of the charge transfer is completely determined by the electronic chemical potential (pi) of the molecule because an electrophile is a chemical species capable of accepting electrons from the environment and its energy must decrease upon accepting electronic charge. Therefore, the electronic chemical potential must be negative, exactly as supported by the obtained values in Table 5. The lower HOMO energy values show that the molecule donating electron ability is the weaker. On contrary, the higher LUMO energy implies that the molecule is a good electron donor. LUMO energy presents the ability of a molecule receiving electron [49]., The high values of the LUMO energy $\left(\mathrm{E}_{\text {LUMO }}\right)$ of the metal complexes under study reveal the easy of the metal ions to accept electrons from ligand which increase the stability of the formed metal complexes [49].

c) The LUMO - HOMO energy gap $(\Delta \mathrm{E})$ is an important stability index that should be considered. As the LUMO - HOMO energy gap decreases, interactions between the reacting species become stronger and as a result the stability of the formed metal complexes increases [50]. The values of $\Delta \mathrm{E}$ indicated that the ligand under investigation has high inclination to bind with the metal ions. From the calculated values of binding energy we notice that there is an increase of the values of binding energy of the complexes compared to that of the ligands which indicates that the stability of the formed metal complexes is higher than that of the free ligand. The calculated heat of formation values indicated a large stabilization of the formed metal complexes compared to the free ligand, since they have heat of formation values lower than that of the free ligand. The metal complexes have higher values of the dipole moment than that of the free ligand.

Table 4. The calculated quantum chemical parameters of the ligand (HL) and its complexes

\begin{tabular}{|c|c|c|c|c|c|c|c|c|}
\hline Compound & $\mathbf{E}_{\text {номо }}$ & $\mathbf{E}_{\text {LUMO }}$ & $\Delta \mathbf{E}$ & $\chi$ & $\eta$ & $\boldsymbol{\sigma}$ & $\mathbf{P i}$ & $\Delta \mathbf{N}_{\max }$ \\
\hline HL & -8.8042 & -1.38107 & 7.42313 & 5.092 & 3.71156 & 0.2694 & -5.0926 & 1.372 \\
\hline$\left[\mathrm{Co}(\mathrm{L}) \cdot 2 \mathrm{H}_{2} \mathrm{O}\right] 4 \mathrm{H}_{2} \mathrm{O}$ & -5.794 & -1.42102 & 4.372 & 3.607 & 2.186 & 0.457 & -3.607 & 1.65 \\
\hline$\left[\mathrm{Ni}(\mathrm{L}) \cdot 2 \mathrm{H}_{2} \mathrm{O}\right] \mathrm{H}_{2} \mathrm{O}$ & -8.67798 & -1.445752 & 6.97112 & 5.061 & 3.4855 & 0.2869 & -3.4855 & 1.4522 \\
\hline$\left[\mathrm{Cu}(\mathrm{L})_{2}\right] 2 \mathrm{EtOH}$ & -8.41687 & -1.35331 & 7.06356 & 4.885 & 3.532 & 0.2831 & -4.885 & 1.383 \\
\hline$[\mathrm{Zn}(\mathrm{L})] 6 \mathrm{H}_{2} \mathrm{O}$ & -8.39733 & -1.68822 & 6.70911 & 5.042 & 3.354 & 0.2982 & -5.0425 & 1.5034 \\
\hline
\end{tabular}

Table 5. Theoretical parameters of the molecular modeling of $(H L)$ and its complexes

\begin{tabular}{|c|c|c|c|c|c|}
\hline $\begin{array}{l}\text { The assignment of the } \\
\text { theoretical parameters }\end{array}$ & (HL) & {$\left[\mathrm{Co}(\mathrm{L}) \cdot 2 \mathrm{H}_{2} \mathrm{O}\right] 4 \mathrm{H}_{2} \mathrm{O}$} & {$\left[\mathrm{Ni}(\mathrm{L}) \cdot 2 \mathrm{H}_{2} \mathrm{O}\right] \mathrm{H}_{2} \mathrm{O}$} & {$\left[\mathrm{Cu}(\mathrm{L})_{2}\right] 2 \mathrm{EtOH}$} & {$[\mathrm{Zn}(\mathrm{L})] 6 \mathrm{H}_{2} \mathrm{O}$} \\
\hline Total energy $(\mathrm{Kcal} / \mathrm{mol})$ & -114204.0156 & -257709.2 & -266127.4688 & -255073.156 & -228333.531 \\
\hline Binding energy (Kcal / mol) & -5863.44 & -12823.608 & -12303.703 & -11786.97 & -11623.7509 \\
\hline Electronic energy (Kcal / mol) & -928708.37 & -3287187.5 & -3318731 & -3021344 & -2868327.2 \\
\hline Heat of formation $(\mathrm{Kcal} / \mathrm{mol})$ & 43.72 & $-347,79$ & -267.459 & 3.843611 & 117.5409 \\
\hline Dipole moment (Debye) & 7.691 & 8.933 & 6.412 & 2.061 & 3.705 \\
\hline $\mathrm{E}_{\text {LUMO }}(\mathrm{ev})$ & -1.38107 & -1.421 & -1.445752 & -1.35331 & -1.68822 \\
\hline
\end{tabular}

\subsubsection{BondLengths Calculations}

Table 6. Calculated bond lengths of the ligands and some of their metal complexes

\begin{tabular}{lll}
\hline \multirow{2}{*}{ Compound } & Bond length $\left.\mathbf{( A}^{\circ}\right)$ & \\
\cline { 2 - 3 } & $(\mathbf{C}=\mathbf{N})_{\text {azomethine }}$ & $(\mathbf{C}-\mathbf{O})_{\text {phenolic }}$ \\
\hline $\mathrm{HL}$ & 1.298 & 1.36053 \\
{$\left[\mathrm{Co}(\mathrm{L}) \cdot 2 \mathrm{H}_{2} \mathrm{O}\right] 4 \mathrm{H}_{2} \mathrm{O}$} & 1.4558 & 1.2916 \\
{$\left[\mathrm{Ni}(\mathrm{L}) \cdot 2 \mathrm{H}_{2} \mathrm{O}\right] \mathrm{H}_{2} \mathrm{O}$} & 1.4528 & 1.30576 \\
& 1.4527 & 1.3049 \\
{$\left[\mathrm{Cu}(\mathrm{L})_{2}\right] 2 \mathrm{EtOH}$} & 1.48069 & 1.332 \\
& 1.443 & 1.28845 \\
{$[\mathrm{Zn}(\mathrm{L})] 6 \mathrm{H}_{2} \mathrm{O}$} & 1.43839 & 1.28204 \\
\hline
\end{tabular}

A comparison between the selected bond lengths $(\mathrm{C}=\mathrm{N}$ and $\mathrm{C}-\mathrm{OH}$ phenolic) of the ligand and their some metal complexes is illustrated in Table 6. From the data obtained we observed that there is an elongation in the bonds of the active group of the ligand taking part in coordination with the metal ions after complexation, which correlates with the experimental IR frequencies. As there is an elongation in the bonds a lower energy of the vibration frequency is needed [51].

\section{Biological Activities}

\subsection{Antibacterial and Antifungal Assays}

The biological activities of synthesized Schiff base (HNMABSQ), its $\mathrm{Co}(\mathrm{II}), \mathrm{Ni}(\mathrm{II}), \mathrm{Cu}(\mathrm{II}), \mathrm{Zn}(\mathrm{II})$ complexes and nano $\mathrm{Cu}$ - HNMABSQ complex were studied for antibacterial and antifungal properties by the agar diffusion method in DMF solvent against Escherichia coli, Staphylococcus aureus, Bacillus subtilisand Salmonella typhi bacteria ,Candidaalbicans and, Aspergillus fumigatus fungi. The results of antibacterial and antifungal activity of tested 
compounds were discussed as follows:

A comparative study of the ligand and complexes indicated that most complexes exhibited higher antimicrobial activity than the free ligand. Such increased activity of the complexes can be explained on the basis of Overtone's concept [52] and Tweedy's chelation theory [53]. These complexes also disturb the respiration process of the cell and thus block the synthesis of the proteins, restricting the further growth of the organism. Furthermore, the mode of action of the compound may involve the formation of a hydrogen bond through the azomethine group with the active center of the cell, resulting in interference with the normal cell processes. In general, metal complexes are more active than ligands because metal complexes may serve as a vehicle for the activation of ligands the principle cytotoxic species [50]. Nano-Cucomplex showed higher antimicrobial activity than the free ligand and its metal chelates, this is due to their high surface to volume ratio are very reactive, can easily interact with other particles and increase their antimicrobial efficiency [54] Also, this difference in activities is related to the complex formation between Schiff base ligand (HNMABSQ) and colloidal $\mathrm{Cu}$ - nanoparticles, leading to super strong materials increase their antimicrobial efficiency.

Generally, the orders of antimicrobial activity are:

$\mathrm{Cu}$-nano complex $>\mathrm{Zn}$ (II) complex $>\mathrm{Co}(\mathrm{II})$ complex $>$ $\mathrm{Ni}(\mathrm{II})$ complex $>\mathrm{Cu} \mathrm{L},>\mathrm{L}$

\subsection{Anticancer Evaluation}

This study aimed to evaluate the growth inhibitory on human cancer liver cells. In this work, three compounds, namely sulpha drug ligand (HNMABSQ), [Cu(HNMABSQ) $)_{2}$ $2 \mathrm{EtOH}$, and nano $\mathrm{Cu}$ - HNMABSQ Complex were chosen as representative examples to evaluate their cytotoxic activity against carcinoma cell line(HePG-2). Doxorubicin was used as a reference drug. The percent inhibition of cell viability was determined using Eliza Tecan Sunrise $570 \mathrm{~nm}$ filters with reference to the control values (without test compound). The data was subjected to linear regression analysis and the regression lines were plotted for the best fit. The IC50 (inhibition of cell viability) concentrations were calculated using the respective regression equation. According to the obtained results, the examined carcinoma cell lines appeared to be sensitive to all of the tested compounds. The data showed that high cytotoxic activity against (HePG-2) carcinoma cells lines, so all tested compounds inhibited the growth of the liver cancer cell.

\section{Conclusions}

Copper- nano complexes were prepared and characterized. These compounds have a great interest recently due to unique physical and chemical properties and low cost of preparation in which have great applications as antimicrobial and anticancer materials.

The newly synthesized sulpha drug Schiff base acted as a mono-negative bidentate ligand. The metal ion was coordinated through the phenolic oxygen and the nitrogen of the azomethine group.

Based on the above results gained from elemental and thermal analyses, conductance measurements, IR, UV/Vis, ESR spectra as well as magnetic moments studies, the geometric structures of the complexes under investigation can be formulated as follows:

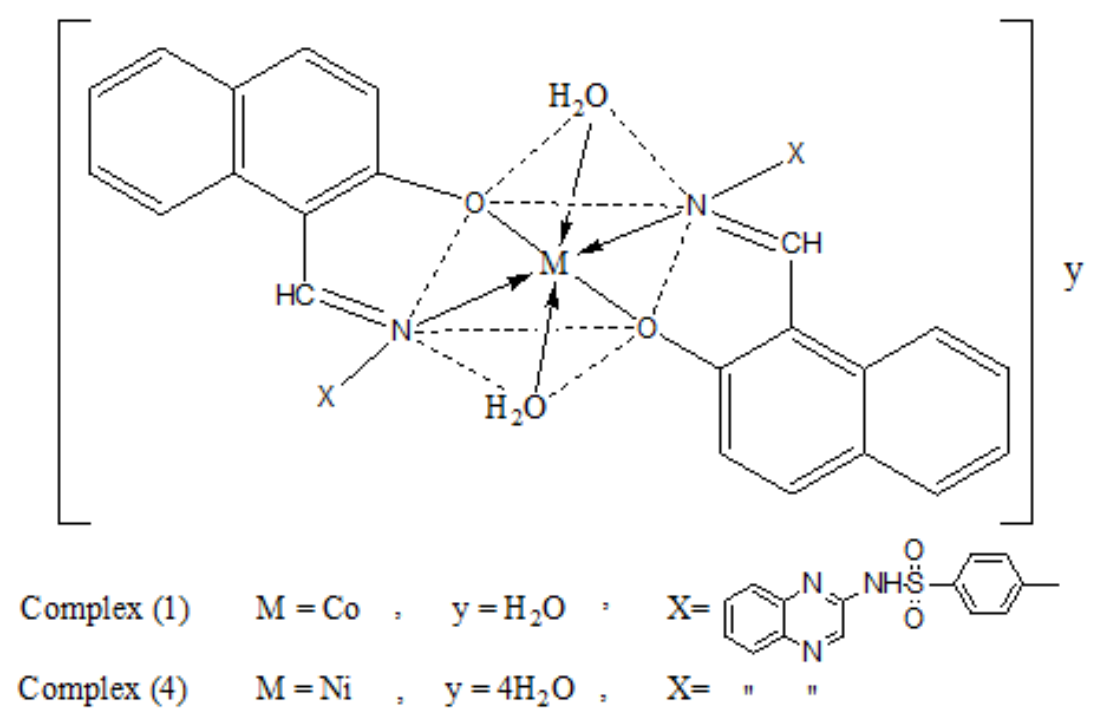




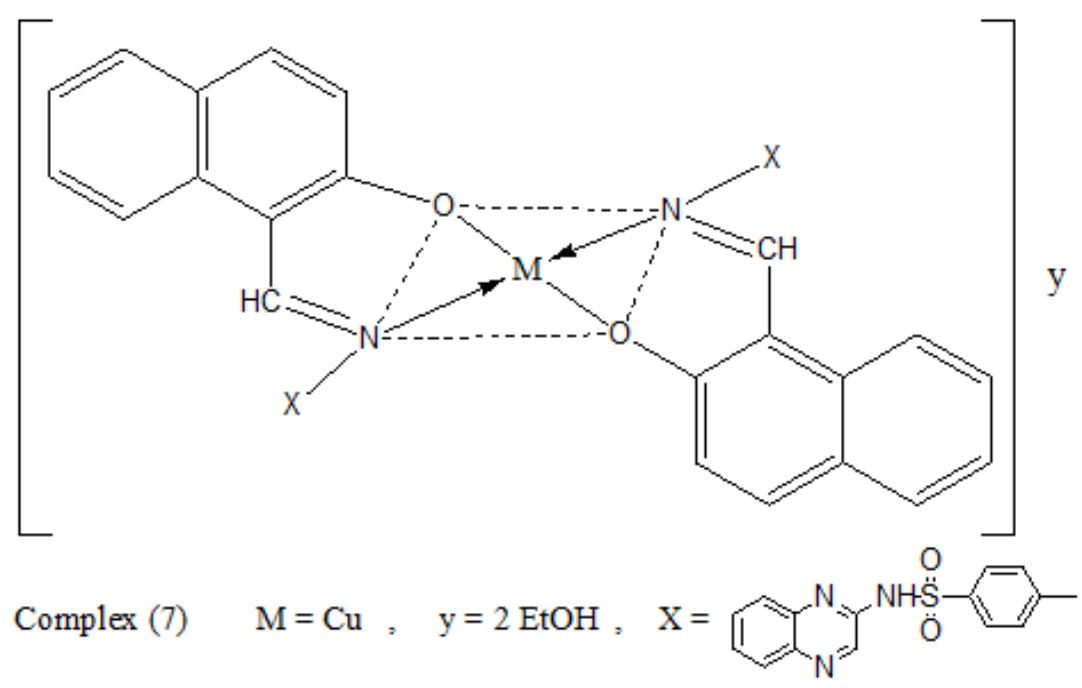

Complex (10) $\mathrm{M}=\mathrm{Zn}, \mathrm{y}=6 \mathrm{H}_{2} \mathrm{O}, \mathrm{X}=$ " "

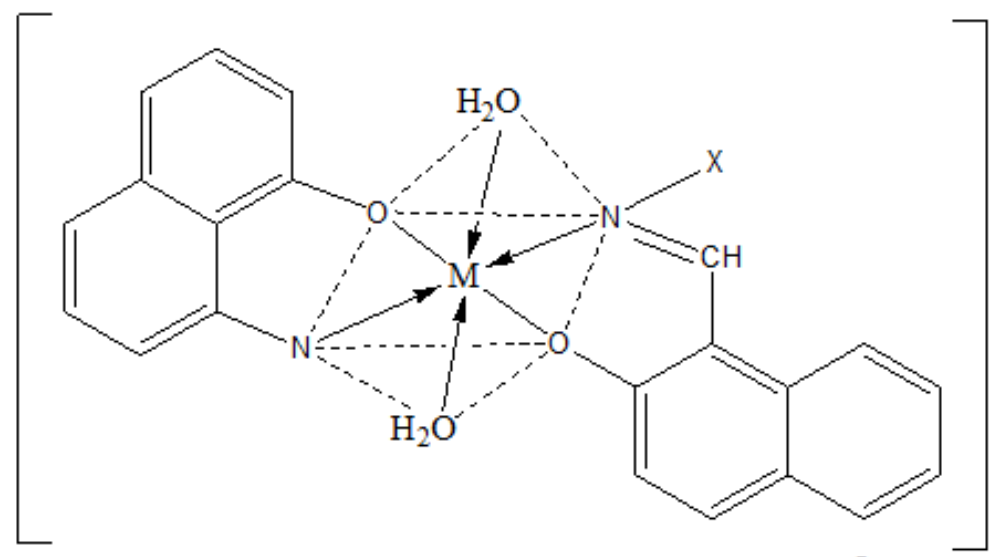

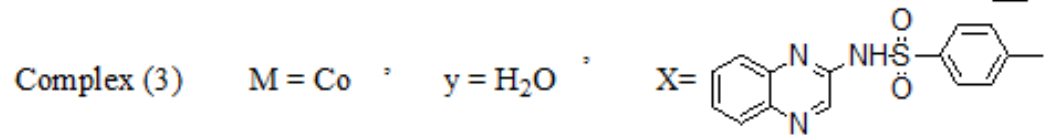

Complex (6) $\mathrm{M}=\mathrm{Ni}, \mathrm{y}=\mathrm{EtOH}, \mathrm{X}=$ " "

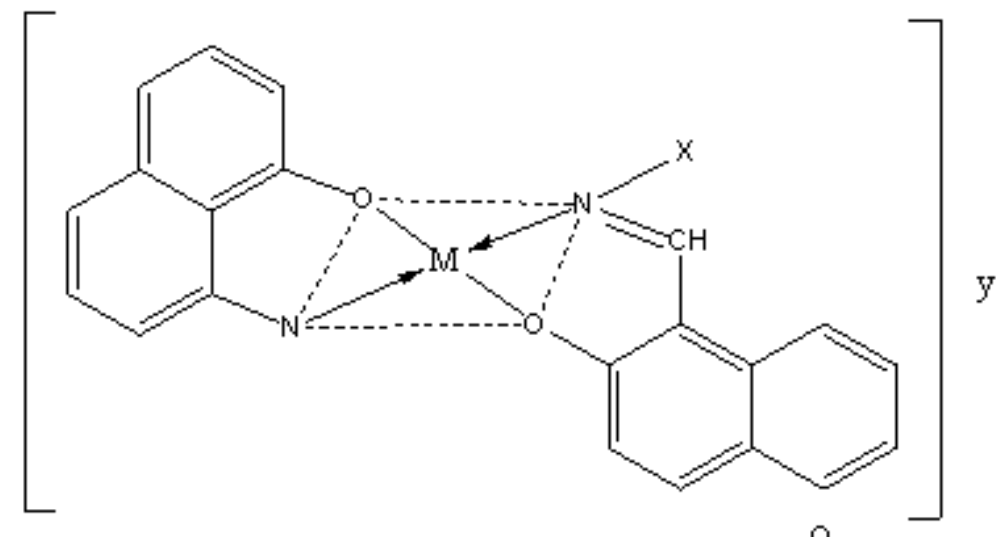

Complex (9) $\mathrm{M}=\mathrm{Cu}, \quad \mathrm{y}=\mathrm{EtOH}, \mathrm{x}=\mathrm{CON}_{\mathrm{N}}^{\mathrm{N}}$

Complex (12) $\mathrm{M}=\mathrm{Zn}, \quad \mathrm{y}=2 \mathrm{H}_{2} \mathrm{O}, \mathrm{X}=\quad$ " $"$ 


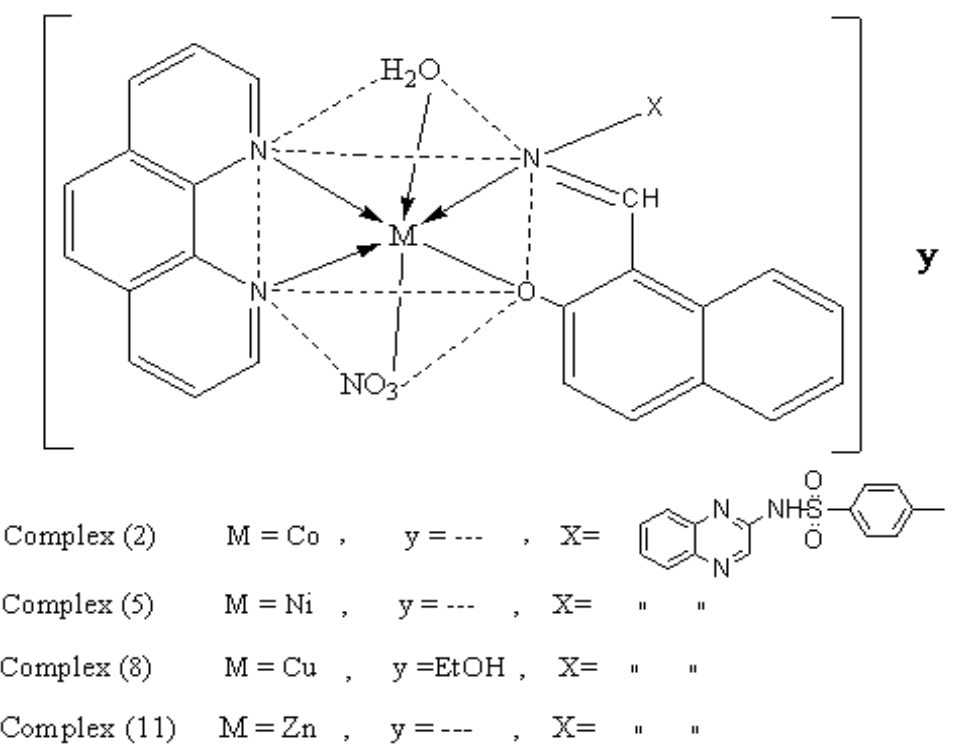

\section{Acknowledgement}

The authors are thankful to Prof.. Hesham Abd-El-Fatah, dean of nanotechnology department -City of science researches and technological application at New Borg ElArab City, Alexandria, Egypt, for his help to facilitate the work of the SEM images to our nano compounds.

\section{References}

[1] S. Kumar, D. N. Dhar, P. N. Saxena, J. Scientific and Industrial Research. 68 (2009) 181-187.

[2] M. M. H. Khalil, E. H. Ismail, G. G. Mohamed, E. M. Zayed and A. Badr, Open Journal of Inorganic chemistry, 2 (2012) 13-21.

[3] Katarzyna BRODOWSKA, Elżbieta ŁODYGACHRUŚCIŃSKA, CHEMIK, 68 (2014) 129-134.

[4] A. Iqbal, H. L. Siddiqui, C. M. Ashraf, M. H Bukhari C. M. Akram, Pharm. Bull. 55 (2007) 1070.

[5] A. Lalehzari, J. Desper, C. J. Levy, Inorg. Chem. 47(2008) 1120 .

[6] S. Shit, S. Sen, S. Mitra, D. L. Hughes, Transition Met. Chem3. (2009) 269.

[7] Xu, B.; Jiang, W.; Zhang, J.; Tang, Y.; Li, J. Transition Met. Chem. 34 (2009) 293.

[8] G. B.. Bagihalli, P. G. Avaji, S. A. Patil, P. S. Badami, Eur. J. Med. Chem. 43 (2008) 2639-2649.

[9] Z. H. Chohan, M. Arif, A. J. Rashid, J. Enzyme Inhib. Med. Chem. 23 (2008) 785.

[10] K. Siddappa and Nabiya Sultana Mayana, Int J Pharm Bio Sci, 5(4) (2014) 162-174.

[11] H. Mastubara, Botyk Kogaku, (1954) 15.
[12] M. Forbes F. Zilliikan, G. Robert, P. Gyorgy, J. Am. Chem. Soc. 80 (1985) 385.

[13] A. H.. Rahaman, E. M. Khendel, J. Indian. Chem. Soc. 58 (1981), 404.

[14] R. A.. Scherrer, US Patent. 3 (1975), 927.

[15] S. B. Kadin, J. Med. Chem. 15 (1972) 551.

[16] J. W. Mason, N. J. Eng, Med. Chem. 31(1987) 455.

[17] Y. Kawas, M. Nakayama, P. Tamatskuri, Bull. Chem. Soc. Japan. 35 (1962) 149.

[18] C. M. da Silva, D. L. Da Silva, L. V. Modolo, R. B. Alves, M. A. De Resende, C. V. B. Martins, A. de Fatima, J. Adv. Res. 2 (2011) 1-8.

[19] E. J. Threlfall, I. S. T. Fisher, L. Ward, H. Tschape, P. GernerSmidt, Microb. Drug Resist. 5 (1999) 195-199.

[20] J. F. Prescott, J. D Baggot, R. D. Walker, In Antimicrobial Therapy in Veterinary Medicine, Iowa State University Press, Ames, Iowa, (2000).

[21] J. Sambrook, E. F. Fritsch, T. Maniatis, Molecular Cloning, A Laboratory Manual, 2nd ed., Cold Spring Harbor Laboratory, New York (1989).

[22] W. J. Geary, Coord. Chem. Rev. 7 (1971) 81-122.

[23] J. T. Hu, T. W. Odom, C. M. Lieber, Acc. Chem. Res. 32 (5) (1999) 435.

[24] J. D. Holmes, K. P. Johnston, R. C. Doty, B. A. Korgel, Science. 287 (2000) 5457.

[25] N. Agrait, N. J. Rodrigo, S. Vieria, Phys. Rev. B 47 (1993) 12345.

[26] N. Duxin, O. Stephan, C. Petit, P. Bonville, C. Colliex, M. P. Pileni, Chem. Mater. 9(1997) 2096.

[27] Nadia El-Wakiel, Yusif El-Sayed, Mohamed Gaber, Journal of Molecular Structure, 1001 (2011) 1-11. 
[28] R. M. Wang, N. P. He, P. F. Song, Yu-F. He, L. Ding, Z. Q. Lei, Polym. Adv. Technol. 20 (2009) 959.

[29] A. I. Vogel, A Text Book of Quantitative Inorganic Analysis, 3rd ed., Longman ELBS, London. (1968).

[30] S. P. Gubin, N. A. Kataeva, Coordination Chemistry of Nanoparticles, Russ. J. Coord. Chem. 32 (12) (2006) 849.

[31] V. Safarifard, A. Morsali, Ultrason. Sonochem. 19 (2012) 823.

[32] R. S Razavi, M. R. LoghmanEstarki, J. Clust. Sci . 23 (2012) 1097.

[33] N. V. Suramwar, S. R Thakare, N. T. Khaty, Int. J. Nano Dimens. 3 (2012) 75.

[34] A. A. Athawale, P. P Kater, M. Kumar, M. B. Majumdar, copper nanoparticles, Mater. Chem. Phys. 91 (2005) 507-512.

[35] T. M. A. Ismail, A. A. Saleh, M. A. El Ghamry, Spectrochimica Acta Part A. 86 (2012) 276

[36] K. Nakamoto, Infrared and Raman Spectra of Inorganic and Coordination Compounds, 4th ed., JohnWiley, Nature. 68 (1964) 201.

[37] A. W. Coats, J. P. Redfern Metal Chem. 26 ( 2001) 532-537

[38] C. R. Vinodkumar, M. K. Muraleedharan Nair and P. K. Radhakrishnan, J. Therm. Anal. Cal. , 143, 61 (2000); A. A. Frost, R. G. Pearson, Kineticks, Mechanisms, Willey, New York (1961).

[39] A. L Sharma, I. O, singh, H. R. singh, R. M Kadam, M. K Bhide, M. D. Snstry, Transit and Sons, New York, (1986).

[40] O. fOzturk, A Cansiz, M. Koparir, Transit Metal Chem. 32 (2007) 224-227.
[41] A. A. Saleh, J. Coord. Chem. 58 (3) (2005) 255-270.

[42] M. Mashaly, T. M. Ismail, S. B. E. L. Maraghy, H. A. Habib, J. Coord. Chem. 57 (13) (2004) 1099-1123.

[43] A. B. P. Lever, Inorganic Electronic Spectroscopy, Elsevier, New York, (1984).

[44] T. M. A. Ismail, J. Coord. 58 (2) (2005) 141-151.

[45] Y. Bodke, S. S. Sangapure, J. Indian Chem. Soc. 80 (2003) 187.

[46] D. N. Satyanarayana, Electronic Absorption Spectroscopy and Related Techniques, Universities Press (India) Limited, New Delhi, (2001).

[47] N. O. Obi-Egbedi, I. B. Obot, M. I. El-Khaiary, S. A. Umoren and E. E. Ebenso, Int. J. Electrochem. Sci. 6 (2011) 56495675 .

[48] D. Kivelson, R. Neiman, J. Chem. Phys. 35 (1961) 149.

[49] N. Raman A. Sakthivel, K. Rajasekaran, J. Coord. Chem. 62 (2009) 1661.

[50] S Belaid, A. Landreau, S. Djebbar, O. Benali-Baitich, G. Bouet, J. P. Bouchara, J. Inorg. Biochem. 55(2008)102,

[51] D. Kivelson, R. Neiman, J. Chem. Phys. 35 (1961) 149.

[52] A. Kulkarni, S. A Patil, P. S. Badami, Eur. J. Med. Chem. 44 (2009) 2904-2912.

[53] N. Raman, A. Sakthivel, K. Rajasekaran, J. Coord. Chem. 6 (2009) 1661.

[54] S. Amer, N. El-Wakiel, H. El-Ghamry, Journal of Molecular Structure 1049 (2013) 326-335. 